critical mass for a neutron configuration breaks up into many smaller objects, a point of view proposed several years ago ${ }^{12}$. Some fragments may be thrown out of the nebula, at high speeds, and thus there might be quite an extensive population of such objects in and around our galaxy. The recent discovery that the pulsar $N P 0527$ lies only about a degree from the Crab and may have been thrown out of it at relativistic speed (preprint by E. C. Reifenstein, W. D. Brundage and D. H. Staclin) supports this view. Only those objects with velocities $\approx 500 \mathrm{~km} \mathrm{~s}^{-1}$ would still, after 1,000 $\mathrm{yr}$, lie inside the Crab nebula. It is again tempting to speculate that it is the energy residing in these fragments and being released in the form of high energy particles which maintains the activity in the Crab. It should also be pointed out that there is considerable evidence from the extragalactic radio sources that they are generated by coherent objects which are thrown out in a large scale explosion from the nucleus of a galaxy or a quasi-stellar objoct ${ }^{13}$.

This work was supported in part by the US National Science Foundation and in part by NASA.

\section{G. Burbidge}

University of California,

San Diego.

\section{F. HOYLE}

Institute of Theoretical Astronomy,

Cambridge.

Received January 14, 1969.

1 Oort, J. H., and Walraven, T., Bull. Astron. Insts. Neth.,12, 285 (1956).

${ }^{2}$ Colgate, S., and Johnson, M. H., Thys. Rev. Lett, 5, $235(1960)$. Colgate, S.

${ }^{3}$ Hewish, A., and Okoyc, S. E., Nature, 207, 59 (1965).

+ Rees, M. J., Astrophys. Lett., 2, 1 (1968).

s Demoulin, M-H., and Burbidge, G., Astrophys. J., 154, 3 (1968).

"Staelin, D. H., and Rcifenstein, F. C., Science, 162, 1481 (1968).

' Gold, T., Nature, 218, 731 (1968).

${ }^{8}$ Bowyer, S., Byram, E. 'L., Chubb, T. A., and Friedman, H., Science, 146, 912 (1964).

Peterson, L., Jacobson, A., Pelling, R., and Schwartz, D., Canad. J. Phys, 47,437 (1968).

"Oda, M., J3radt, H., Garmirc. G., Spada, G., Sreenkantan, 13. V., Gursky, H. Giacconi, R., Gorenstein, P., ind Waters, J. R., Astrophys. J., Lá (1967)。

"Tucker, W. H., Astrophys. J., 148, 745 (1967).

1 Hoyle, F., and Fowler, W. A., Quasi-Stellar Sources and Gravitational Collapse, 17 (Univ. Chicago Press, 1965). Hoyle, F., Fowler, W. A. Burbidge, G. R., Nature, 216, 1287 (1967).

\section{Preliminary Results of Measurements of Deep Currents in the Pacific Ocean}

Hrom June 18 to August 5, 1968, the STYX expedition of the Scripps Institution of Oceanography made measurements of deep flow in the South Pacific Ocean. As carly as 1871 (ref. 1) it had been suggested that the deep and bottom waters of the North Pacific Ocean are not formed by modification of North Pacific surface waters, but have flowed in through the South Pacific from other areas. Wust ${ }^{2}$ has traced the flow of cold bottom water (deeper than $4,000 \mathrm{~m}$ ) from the Antaretic Circumpolar Current to the western North Pacific; the obscrved temperature variation beyond was too small to indicate a clear path. Other investigators ${ }^{3,4}$ have confirmed his results by the distributions of dissolved oxygen and salinity, and some further indirect evidence of a deep strong northward flow across $29^{\circ} \mathrm{S}$ has recently been submitted ${ }^{5,6}$.

A flow that is strong enough and continuous enough to be detected from temperature variations might be strong enough to be measured directly by a simple current meter, especially in an area where the bottom topography limits all the deep flow to a narrow channel. The recent charts by Udintsev et al. ${ }^{7}$ and Menard $^{8}$ suggested that such a channel might exist in the arca between the Samoan and
Tuamotu islands, though the soundings were not sufficient to be sure. The STYX expedition located a deep channel passing through at about $9^{\circ} \mathrm{S} 169^{\circ} \mathrm{W}$; this seems to be the only passage connecting the South and North Pacific at depths greater than $5,000 \mathrm{~m}$. Sill depth is about $5,200 \mathrm{~m}$ and the passage seems to be about $50 \mathrm{~km}$ wide at the $5,000 \mathrm{~m}$ level and $200 \mathrm{~km}$ wide at the $4,000 \mathrm{~m}$ level.

The current meters were similar to those used at depths of about 4,000 $\mathrm{m}$ off California ${ }^{9}$. 'They consist of a rotor, a vane, a recorder and a float and anchor. A release-link that can be set for various intervals up to about 5 days was used. The instruments fall freely to the bottom and operate for a pre-set period and then release the anchor and return to the surface where they transmit a radio signal to aid in their recovery. Work in the dcep water off California ${ }^{9}$ had shown a predominantly semidiurnal variation of amplitude of about $2 \mathrm{~cm} \mathrm{~s}^{-1}$ about a mean of the same order: records at least as long as $24 \mathrm{~h}$ were required before a useful average could be taken.

The STYX expedition surveyed the channel and made measurements of water characteristics as well as the current measurements. The current meters were placed at various depths from 30 to $1,000 \mathrm{~m}$ above the bottom in depths as great as $5,900 \mathrm{~m}$ (in the Tonga Trench), but most of the forty-four series were made close to the bottom in depths between 4,500 and $5,500 \mathrm{~m}$. In the carlier part of the expedition short period drops were made to locate areas of higher speed. Once the channel was located, records from 24 to $72 \mathrm{~h}$ (with one as long as $95 \mathrm{~h}$ ) were obtained.

Measurements in depths less than $4,400 \mathrm{~m}$ in the surrounding area usually showed low average speeds (less than $5 \mathrm{~cm} \mathrm{~s}^{-1}$ ) with no consistency in the directions. Those within the narrow part of the channel, at depths greater than $4,800 \mathrm{~m}$, and operating for periods from 11 to $46 \mathrm{~h}$, showed average flows of from 5 to $15 \mathrm{~cm} \mathrm{~s}^{-1}$ with directions between $013^{\circ} T$ and $065^{\circ} T$; the largest tidal amplitude ostimated from the records in the channel was about $3 \mathrm{~cm} \mathrm{~s}^{-1}$.

The highest average speed was in the channel at $4,806 \mathrm{~m}$, and was $15 \mathrm{~cm} \mathrm{~s}^{-1}$ toward $023^{\circ}$, averaged over $43 \mathrm{~h}$. The maximum speed during this series was $19.5 \mathrm{~cm} \mathrm{~s}^{-1}$ toward $005^{\circ} T$ and the lowest was $11 \mathrm{~cm} \mathrm{~s}^{-1}$ toward $030^{\circ}$. The tidal amplitude estimated from the record was $0.4 \mathrm{~cm} \mathrm{~s}^{-1}$ for the diurnal and $1.5 \mathrm{~cm} \mathrm{~s}^{-1}$ for the semidiurnal. Thus not all of the variation was tidal. In the further analysis we shall compare the records with the nearest tide stations.

The longest individual record was $95 \mathrm{~h}$, taken in the wide basin to the south that feeds the channel. The basin was estimated to be about $330 \mathrm{~km}$ wide at the $5 \mathrm{~km}$ level and $470 \mathrm{~km}$ wide at the $4 \mathrm{~km}$ level. Average flow at $3 \mathrm{~m}$ above the bottom in $5,275 \mathrm{~m}$ depth was $4.4 \mathrm{~cm} \mathrm{~s}^{-1}$ toward $343^{\circ} \mathrm{T}$ (leading directly toward the channel). The tidal amplitude was calculated from the record to be about $2.5 \mathrm{~cm} \mathrm{~s}^{-1}$ for the somidiurnal and $1.3 \mathrm{~cm} \mathrm{~s}^{-1}$ for the diurnal components.

$\cdot$

JosepH L, REID

Scripps Institution of Oceanography,

La Jolla, California.

Received December 31, 1968.

Prestwich, J., Q. J. Geol. Soc. London, 27, 30 (1871).

${ }^{2}$ Wust, G., Veroff. Inst. Meeresk. Univ. Berlin, 20, 1 (1929).

${ }^{3}$ Wooster, W. S., and Volkmann, G. H., J. Geophys. Res., 65, 1239 (1960).

4 Knauss, J. A., J. Geophys. Res., 67, 3943 (1962).

Warren, 13. A., Stroup, E. D., Stommel, H., and Reid, J. L., Trans. Amer. Geophys. Un., 49, 200 (1968).

${ }^{6}$ Reid, jun., J., Stommel, H., Stroup, E. D., and Warren, G. A., Nature, 21\%, $937(1968)$. Tdintsev, G. B., Agapova, G. V., Beresnev, A. F., Budanova, I. Ia.,
Zatonskii, L. K., Zenkevich, N. L., Ivanov, A. G., Kanaev, V. F., Kucherov, T. P., Larina, N. I., Marova, N. A., Mineev, V. A., and (1963).

${ }^{8}$ Menard, H. W., Marine Geology of the Pacific (McGraw-Hill, New York, 1964). ${ }^{\circ}$ Isaacs, J. D., Reid, jun., J. L., Schick, G. R., and Schwartzlose, R. A., 